\title{
KAZAKİSTAN'DA BULUNAN GÖKTÜRK YAZITLARI HAKKINDA
}

\section{Napil BAZÍLHAN*}

\section{Özet}

Kazakistan Cumhuriyeti 1991 yılı Aralık ayında bağımsız oldu. Bağımsız olduktan sonra kendisiyle ilgili bazı kültürel konuları devlet politikası hâline dönüştürdü. Bunların başında dil, tarih ve coğrafya sahalarındaki girişimler yer almaktadır. Kazakistan, Orta Asya'daki en geniş topraklara sahip ülkelerden biridir. Kazakların bu geniş coğrafyaya yerleşmiş olması, tarih boyunca bu toprakların korunmasını daha da zorlaştırmıştır. Bundan dolayı Kazakların özellikle 17. ve 18. yüzyıllardaki hayatları bu geniş coğrafyayı koruma mücadeleleriyle geçmiştir. Avrasya bozkırında geniş bir alanı kaplayan Kazak coğrafyası, tarihî olarak da birçok devletin kurulma ve yıkılma sürecine şahit olmuştur.

Dil çalışmaları açısından Türk dilinin en eski dönemini temsil eden Eski Türkçe dönemi yazılı eserleri bu coğrafyada sıkça görülmektedir. Daha çok Göktürkler Döneminde yazıldığı tahmin edilen bu yazılar genellikle kayalar üzerinde damga şeklinde görülmektedir. Özellikle son y1llarda bu kapsamda yapılan inceleme gezilerinde 9 adet yeni yazılı metin bulunmuştur. Bunlar Tañbalı, Koytubek, Akterek, Kuljabası I, Kuljabası II, Kemer, Kotır II, Bayanjürek ve Karatöbe yazıtlarıdır. Çalışmamızda Kazakistan'da yeni bulunan Göktürk yazılı metinleri tanıtılırken bir yandan da daha önceki okumalardan farklı yeni okuma teklifleri üzerinde durulacaktır.

Anahtar Sözcükler: Göktürkler, Göktürk Alfabesi, Kazakistan, Eski Türkçe.

\section{ON THE GOKTURK INSCRIPTIONS DISCOVERED IN KAZAKHSTAN}

\begin{abstract}
The Republic of Kazakhstan gained independence in 1991. After freedom, they took into account some cultural topics as a government policy. Language, history and geography take place as the pineoring subjects. The Kazakh geography is the one of largest geographies in the Central Asia. Having a very large geography and Kazakhs being settled down in this large region made it hard to guarding the country. Therefore, Kazakhs spent efforts on guarding especially in the $17^{\text {th }}$ and $18^{\text {th }}$ centuries. Kazakh geography, which is located in a large part of the Eurasia steps, has also been a pace for foundation of and collapse of many countries historically.

In view of the language researches, the Ancient Turkish represents the earliest Turkish language periods. The written works belonging to this periods is frequently came a cross in this areas. These works belonging to Gokturk's period is generally marked on rocks. Particularly, in expeditions, 9 new written texts are discovered recently. The names of the written texts are the following: Tañbalı, Koytubek, Akterek, Kuljabası I, Kuljabası II, Kemer, Kotır II, Bayanjürek and Karatöbe. The aim of this article is to introduce these new works and suggest new reading techniques.
\end{abstract}

Keywords: Gokturks, Gokturk Alphabet, Kazakstan, Ancient Turkish.

* İlmî Araştırmac1; R. B. Süleymanov Şarkiyat Enstitüsü, Kazakistan, napilbaz@ gmail.com. 


\section{Ø. Giriş}

Avrasya coğrafyasında Göktürk harfleriyle yazılan metinlerin sayısı oldukça fazladır (Kızlasov, 1994; Bazılhan, 2005: 244-245; Vasilyev, 2006: 30-43). Göktürklerin yaz1 geleneğine ait bu dil yadigârlarındaki yazı sisteminin, VI.-IX. yüzyıllarda bu coğrafyada yaygın bir şekilde kullanıldığı görülmektedir. Bu yazılar genellikle kaya üzerine harflerin kazınmasıyla veya yazılmasıyla vücuda getirilmiştir. 1985-2008 yıllarında Orta Asya'da ve özellikle şimdiki Kazakistan topraklarında Göktürk Dönemine ait üç ayna üzerinde 3, küçük bir taş eşya üzerinde 1 ve bir kaya üzerinde 1 adet olmak üzere toplam 5 adet Göktürk harfli metin tespit edilmiştir (Bazilhan, 2008: 117-122).

Kazakistan'da özellikle son dönemlerde bu döneme ait eserlerin incelenmesine ağırlık verilmesiyle birlikte arkeoloji heyetleri tarafından Kazak bozkırlarında inceleme ve araştırma gezileri düzenlenmeye başlanmıştır. Son yıllarda gerçekleştirilen bu araştırmalar sonucunda Göktürk yazı sistemiyle yazılan Tañbalı, Koytubek, Akterek, Kuljabası I, Kuljabası II, Kemer, Kotır II, Bayanjürek ve Karatöbe olmak üzere 9 adet yazılı metin bulunmuştur. Bu yazıtların bulunması eski Türk dili yadigârları açısından Kazakistan ve etrafındaki coğrafyanın önemini artıran bir durum olmuş ve bu sahadaki inceleme çalışmalarına daha da önem verilmeye başlanmıştır. Çalışmamızda Göktürk alfabesiyle yazılan bu 9 adet yazıt tanıtılacak ve bu yazıt metinleri üzerine yapılan çalışmalar ile yorumlu yazı çevirileri üzerinde durulacaktır. Daha önce okunan bazı metinler için ise yeni okuma tekliflerinde bulunulacaktır.

\section{Kazakistan'da Bulunan Köktürk Harfli Metinler}

\subsection{Tañbalı Taş Yazıtı}

Tañbalı Taş yazılı metni, Almatı'ya $170 \mathrm{~km}$ uzaklıkta, şehrin kuzeybatı yönünde bulunmaktadır. Tañbalı Taş yazıtı, adını kayaya kendisiyle birlikte işlenen bir geyik damgasından almaktadır. Kaya üzerine işlenmiş olan bu metni 1991 y1lında arkeolog A. E. Rogojinski keşfetmiştir. Bu keşfini 2004 yılında I. L. Kızlasov ile birlikte hazırladıkları bir makalede yayımlamıştır (Rogojinski ve Kızlasov, 2004: 41-4). Metin tek satırdaki altı adet harften oluşmaktadır. Rogojinski ve Kızlasov'un makalesinde bu yazılar:

"r tï(i) ö(ü)nn > er atï önün Bahadur er ismi Önün" diye okunmuştur. Burada herhangi unvan yazılmadığı hâlde, bu yazının bir insan elinden çıkmış olduğu düşünülerek bu şekilde bir okuma yoluna gidilmiştir. Bu metnin 9. veya 10. yüzyıllara ait bir metin olabileceği de belirtilmektedir. 
Biz, 2011 yılında bu taşın bulunduğu yere tekrar gittik ve kaya üzerindeki yazıları tekrar inceledik. ${ }^{1}$ İncelemelerimiz sonucunda bu metni önceki okumalardan farklı olarak:

" r tï q nčü > er atï aq Inčü Bahadur er adı Ak Inçü" şeklinde metnin yeniden okunması gerektiği görüşündeyiz. Metne ait resim ve çizimler aşağıda gösterilmiştir.

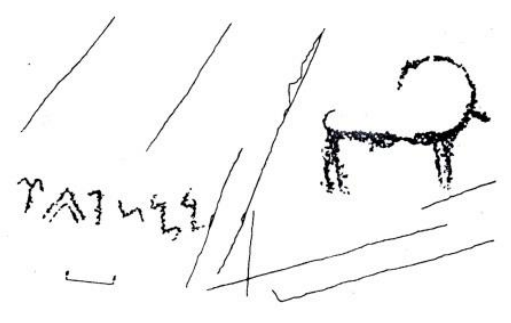

Tañbalı Tas Yazıtı

A. E. Rogojinski'nin Çizimi (2008 yll)

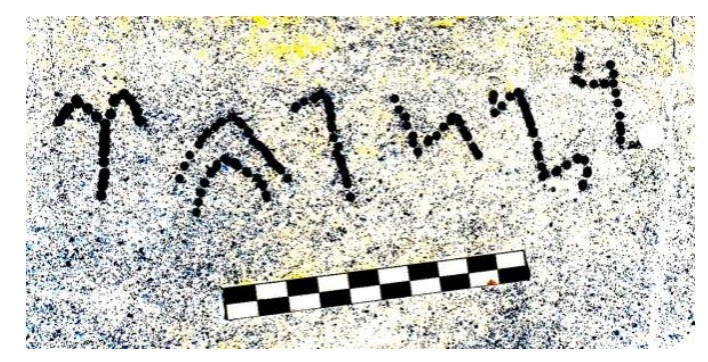

Napil Bazilhan 'in Çizimi (2011 yll $)$

\subsection{Koytübek Yazıtı}

Doğu Kazakistan'ın Kürşim vilayeti, Bulgar Tabıtı ilçesinden 15 kilometre güneybatıda bulunan Koytübek kayasındaki yazılı metinlerdir. Bu yazılar önce "Marka Köl” ve "Ertis" anıtları diye adlandırılmıştır. Mavi renkli bir kaya üzerinde bulunan metin, tek satır hâlinde 3 harften oluşmaktadır. Metnin satır uzunluğu $50 \mathrm{~cm}$ olup harflerinin yüksekliği 5 ile $9 \mathrm{~cm}$ arasında değişmektedir. Yazılar 1985 yılında A. E. Rogojinski tarafinan bulunmuştur (Rogojinski, 2010: 329). Yazı metni hakkında ilk araştırma ise A. S. Amanjolov'a aittir. Amanjolov bu metni:

"ay elig yurtı > ay elinin dura ̆̆ (Ай-элиг)"” şeklinde okumuştur (Amanjolov, 2003: 203).

\footnotetext{
${ }^{1}$ Biz 2011 yılında «Tanbalı taş» kayalarında Aleksey Rogojinski ve restorasyon uzmanı Kırım Altınbekov ile birlikte çalışmıştık ve kendilerine «Gök Tanrı yarlıkasun...» diye teşekkürlerimizi iletiyoruz. Yazıtın bulunan yerinin GPS koordinasiyonu: N- 43. 48.145, E -075.32.015, H-897 / + ,-4 m.
} 


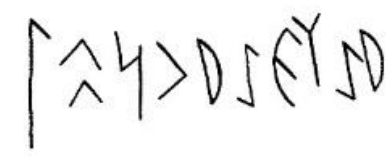

A. Amanjolov'un Çizimi (1985 yzll)
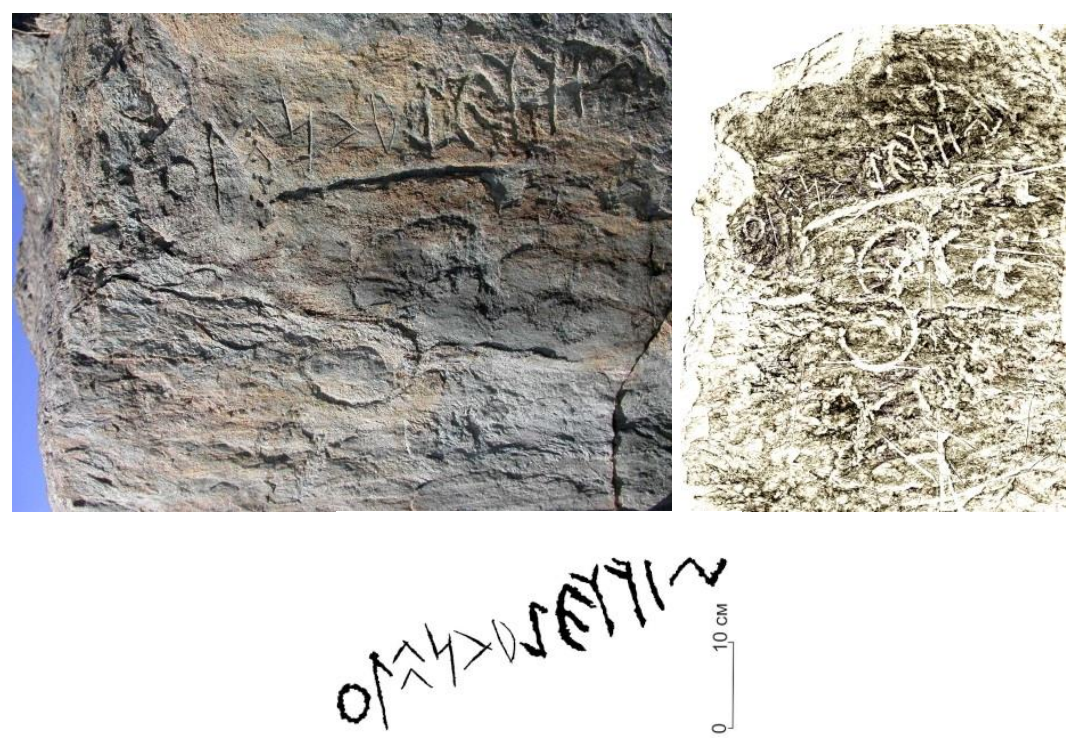

Koytübek Yazıtı

A. E. Rogojinski'nin Fotoğrafi, Estampajı ve Çizimi (2008 yılı)

Bizim bu konudaki görüşlerimiz, A. E. Rogojinski’nin fotoğrafi, estampajı ve çizimine dayanmaktadır. Biz buradaki " $\mathrm{q}$ - $\mathrm{t}$ " harflerinin okunuşlarında bazı farklılıklar olduğunu düşünüyoruz. Bu kayadaki Göktürk metni 12 harfli olarak oyulup yazılmıştır. Biz bu metni:

"t ï k l g a y u r t ï m > Atï külüg yurtïm, Adı / ismi / meşhur yurdum, ocağım, Rusçasını ise ‘Знаменитая земля, моя’” şeklinde okuduk.

\subsection{Akterek Yazitı}

Jambıl iline bağlı Akterek köyünün $4 \mathrm{~km}$ doğusundaki Akterek kayasında bulunmaktadır. Siyah-mavi renk karışımı bir kaya üzerinde bir satır olarak yazılmıştır. Metnin uzunluğu $26 \mathrm{~cm}$ olup damga harflerinin yüksekliği 5-10 cm'dir.

Bu yazıt 2009 y1lında A. E. Rogojinski tarafindan bulunmuştur (Rogojinski, 2010). Bu metni I. L. Kızlasov, "r tïm n > er atïm en Benim adım er-günahkâr, Rusça 'Мое имя мужаэра-грешни' // 'Yücem beni dinle!', Rusça, ‘Боже, услышь меня!’” şeklinde okumuştur (Kizlasov, 2010: 345-346).

Biz ise bu metni, sondaki harflerin okunamamasından dolayı "Er atım, bahadur benim adım, Rusçasını da: 'Имя батыра'” şeklinde okuduk. 

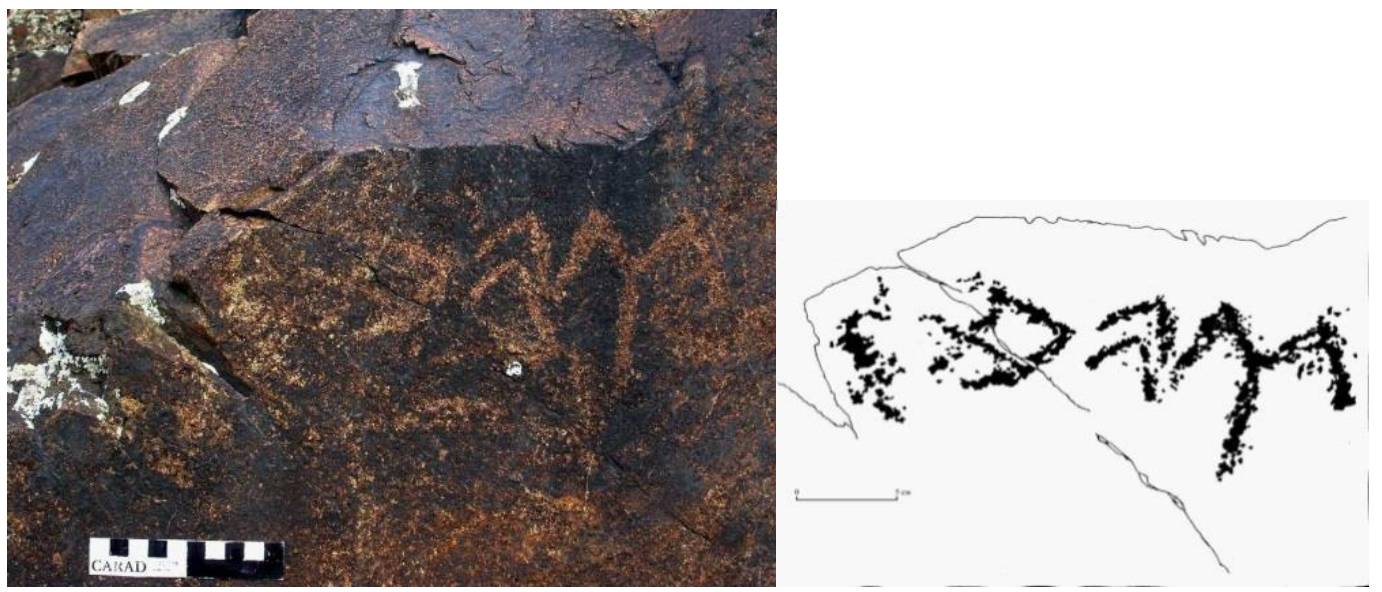

Akterek Yazıtı

A. E. Rogojinski’nin Fotoğrafi ve Çizimi (2008 yılı)

\subsection{Kuljabası I Yazıtı}

Jambıl ilinin Korday ilçesine bağlı Otar istasyonundan $30 \mathrm{~km}$ kuzeybatıda bulunan Kuljabası dağındaki Jaksılık kayasında bulunmaktadır. Kayada tek satır olarak yazılan bu metinde iki harf vardır. Metnin yazı uzunluğu $26 \mathrm{~cm}$ olup harf yüksekliği 5-10 cm'dir. Bu yazıt 2009 yılında A. E. Rogojinski tarafından bulunmuştur (Rogojinski, 2010).

Söz konusu metin üzerinde şimdiye kadar herhangi bir okuma çalışması yapılamamıştır. $\mathrm{Bu}$ metin üzerindeki ilk okuma girişimleri bize aittir. Biz bu metni,

1. er atï aq kiši "Er bahadır adl ismi Ak kişi”",

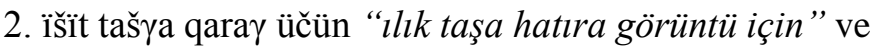

3. ed er "edildi, yazıldı" şeklinde okuduk.

Metni Rusçaya ise "Имя батыра Аккиши, на теплом камне для посмотра, сторожа, сделано" şeklinde aktardık. 


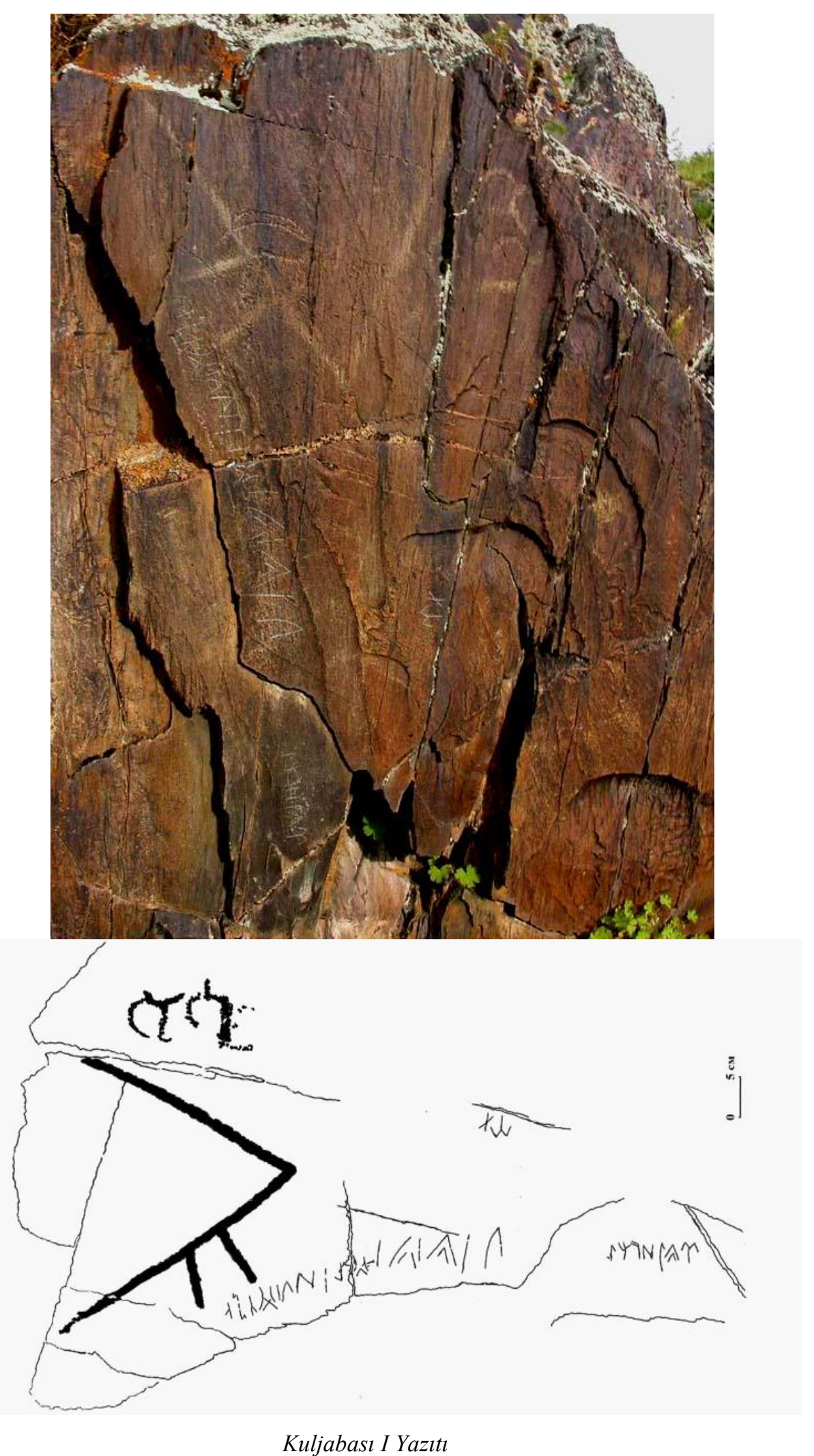

A. E. Rogojinski'nin Fotoğrafi ve Çizimi (2009 yllı) 


\subsection{Kemer Yazitı}

Jambıl iline bağlı Talas ilçesinin Karatav köyünden 20 km kuzeydoğuda bulunan Kızıl Dağı'ndaki Kemer kayasında bulunmaktadır. Mavi granit kaya taş üzerinde 1 satırlık metinden ibarettir. Metnin satır uzunluğu $114 \mathrm{~cm}$ olup, harflerinin yüksekliği 2-5 cm'dir.

Bu yazıt 2009 y1lında A. E. Rogojinski tarafinan bulunmuştur (Rogojinski, 2010: 332333). Metin üzerinde herhangi bir okuma önerisi henüz mevcut değildir².

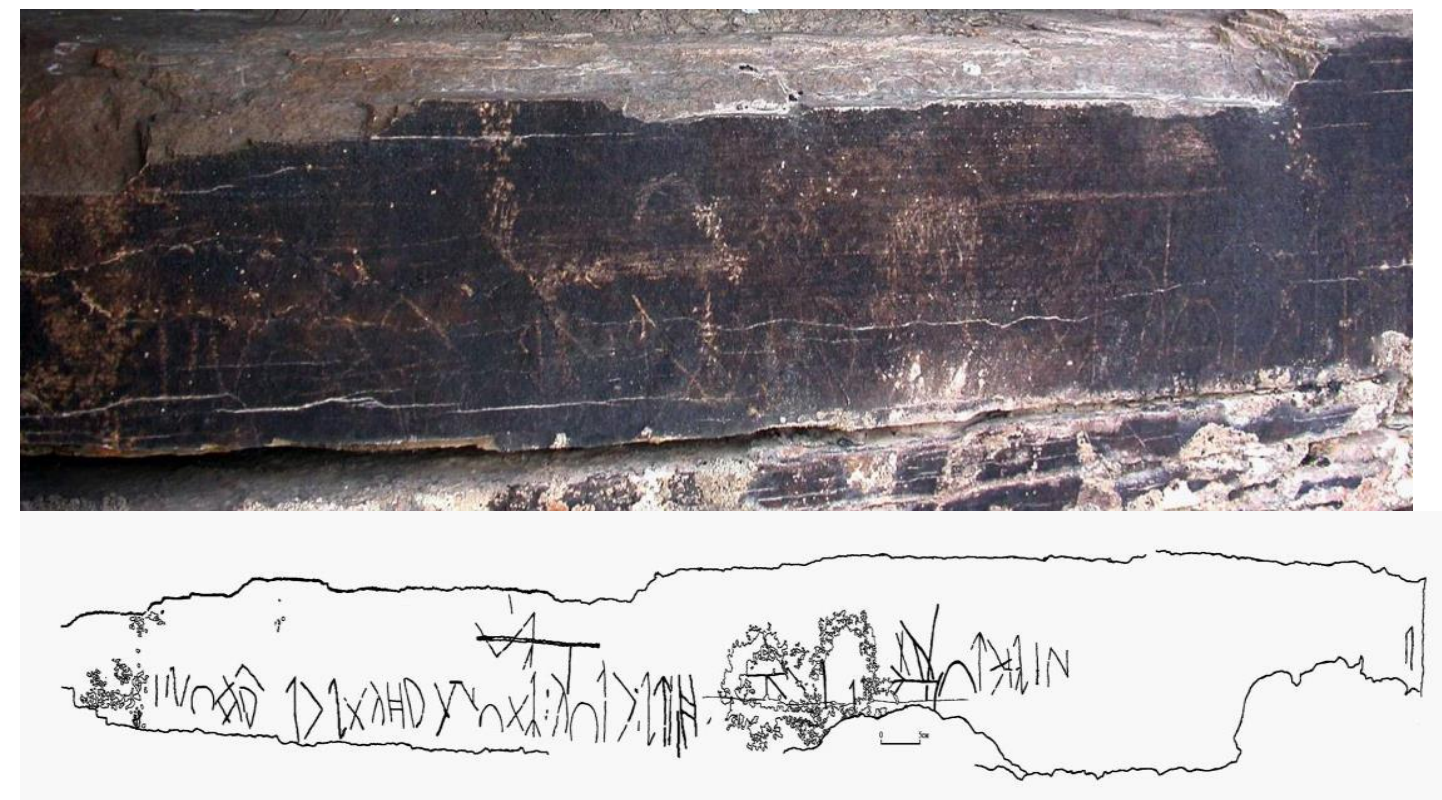

Kemer Yazlti

A. E. Rogojinski'nin Fotoğrafi ve Çizimi (2009 yıll)

\subsection{Kotır II Yazitı}

Jambıl ilinin Talas ilçesine bağlı Karatav köyündeki "Kotır-II" kayasında bulunmaktadır. Bu anıt, 2012 yılında A. E. Rogojinski tarafinan bulunmuştur. Henüz metin üzerinde herhangi bir inceleme bulunmamaktadır. Aynı metin iki kaya üzerine de yazılmıştır. Metinler 5 harften oluşmaktadır. Yazı biçimleri Talas ve Yenisey yazıtlarına benzemektedir.

Metin transkripsiyonu: "q č $\gamma$ a b u - aq čała bu Ak Çaga bu / dur / şeklinde olup Rusçası: ‘то - Ак Чага (имя собств?.)”’ biçimindedir.

\footnotetext{
${ }^{2}$ Biz bu metnin Talas’ta bulunan Açık taş metni, Hazar dönemi yazıtlarıyla ilişkilendirerek bu konuda bir makale hazırlamaktayız. 


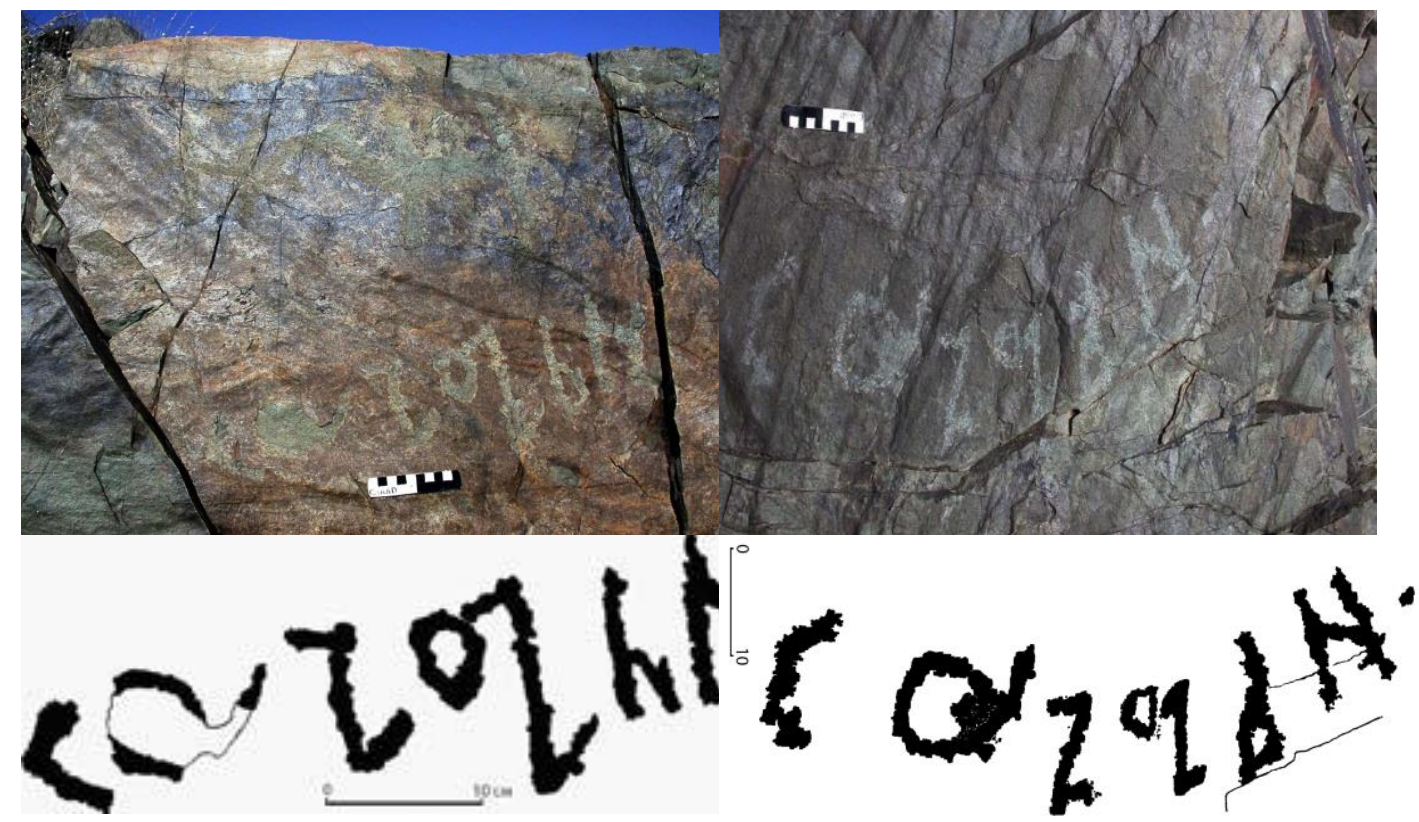

Kotır II Yazıtı

A. E. Rogojinski'nin Fotoğrafi, Estampajı ve Çizimi (2012 yıll)

\subsection{Kuljabası II Yazitı}

Jambıl ili, Korday ilçesine bağlı Otar istasyonundan $30 \mathrm{~km}$ kuzeybatıdaki Kuljabası Dağı'ndaki kayaların birinde tek satırlık metin hâlinde bulunmaktadır. Metnin uzunluğu $78 \mathrm{~cm}$ olup, harflerin yüksekliği 10-11 cm'dir. Bu yazıt 2012 yılında Kazakistan İlimler Akademisi A. H. Margulan Arkeoloji Enstitüsü heyeti tarafınan yapılan ilmi araştırma sonucunda bulunmuştur (Bazılhan, Jeleznyakov, Herman ve Janbulatov, 2013).

Biz bu metni:

“...igidmiš: yer: el: yiče : kü: yegen: ermiš: nenčig? İyi olan yer, ünlü meşhur yegen imiş. Ne yazık ki!, Rusçasını ise 'Превосходный Земля, Эль- народу, очень славный Йеген (племянник) был, жаль!'” olarak okumaktayız.

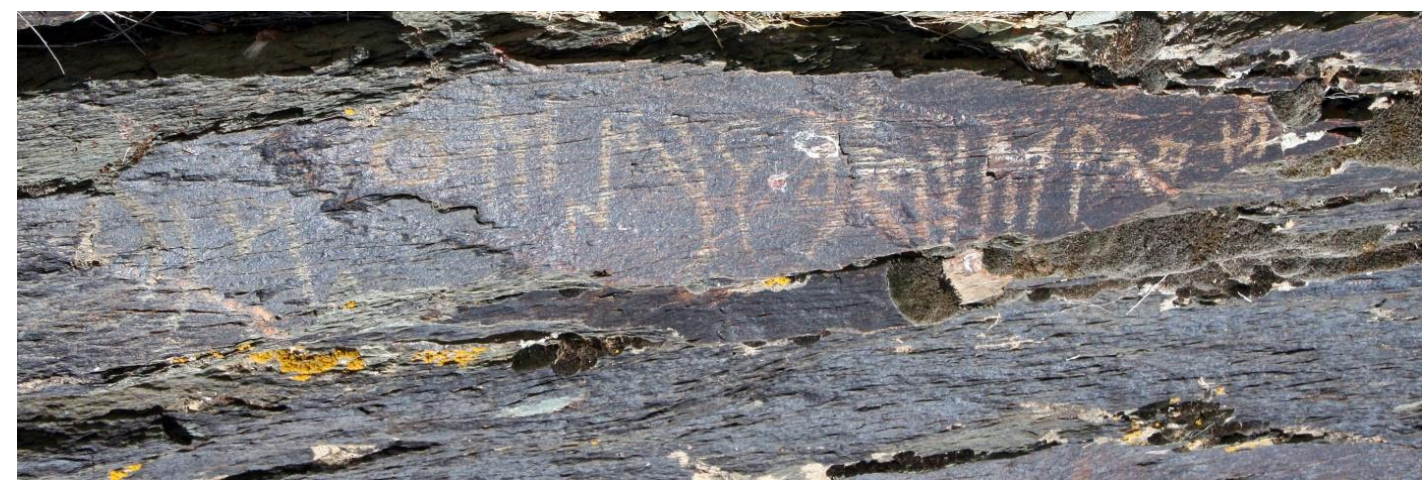

Kuljabası II Yazıtı

Tर्रीR

Uluslararası Türkçe Edebiyat Kültür Eğitim Dergisi Sayı: 3/2 2014 s. 1-12, TÜRKIYE

International Journal of Turkish Literature Culture Education Volume 3/2 2014 p. 1-12, TURKEY 


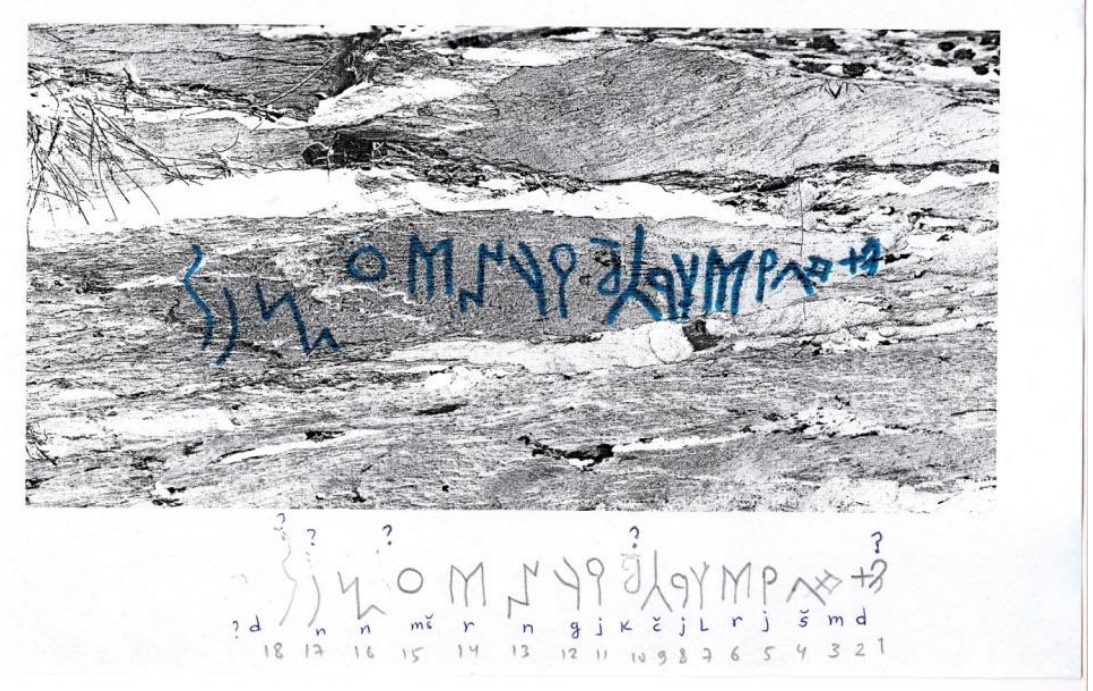

B. Jelezniyakov'un Fotoğrafi ve N. Bazilhan'ın Çizimi (2013 yllı)

\subsection{Bayanjürek Yazıtı}

Bu metin 2009 yılında Z. Samaşev tarafından Almatı ili, Kapal ilçesi, Bayanjürek kırsalında bulunmuştur. Bu metin eldeki fotoğraflar ve çizimlerden hareketle:

“er atım oq" şeklinde okunabilir. Rusçası da “Имя батыра моя Ок” şeklinde olmalıdır. (Samaşev, 2013. 14, 17).
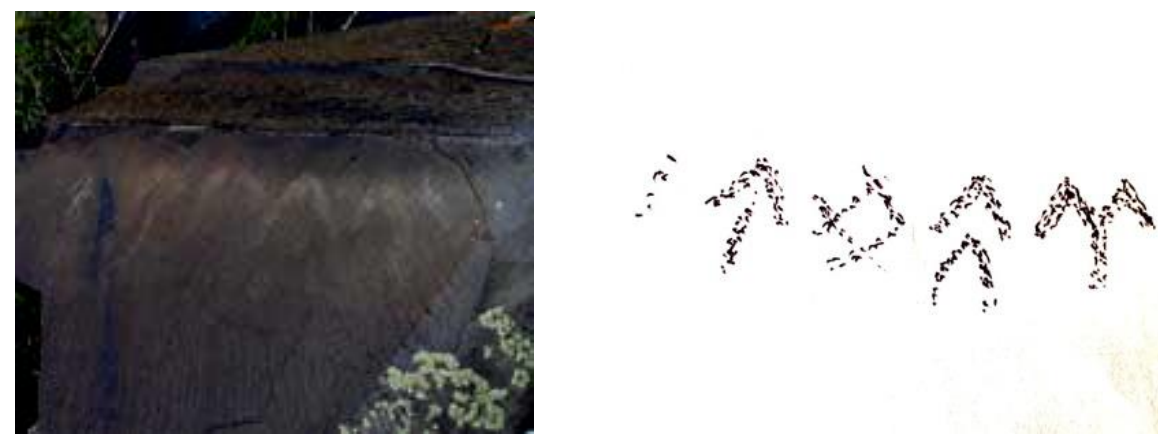

Bayanjürek Yazıtı 


\subsection{Karatöbe Yazıtı}

2008 yılında E. A. Smagulov yönetiminde Güney Kazakistan'1n Karatöbe (Savran) bölgesine düzenlenen arkeolojik kazılarda bulunmuştur. 3 parçalık bir kap üzerinde, birer satırlık 3 metinden oluşmaktadır (Smagulov, 2009).

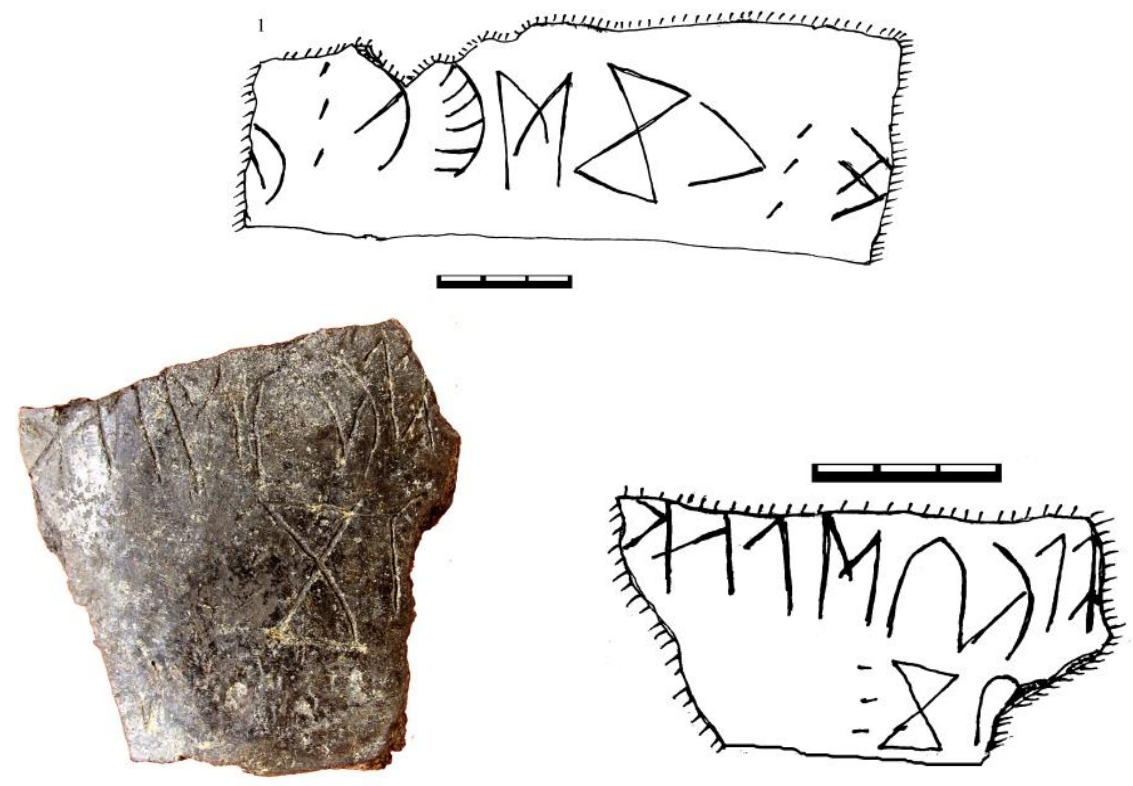

Karatöbe (Savran) Yazıtı

E. A. Smagulova'nın fotoğrafi ve çizimi (2008 yll l)

Biçim olarak Açıktaş ve Hazar dönemi yazıtlarına da benzeyen bu metinler bize göre:

... m...uluq: ergin..y... şeklinde okunmalıdır.

\section{Sonuç}

Kazakistan coğrafi açıdan Türk Cumhuriyetleri içerisinde en geniş topraklara sahip ülkedir. Orta Asya bozkırında bu denli geniş toprakların kazanılması ve muhafaza edilmesi elbette kolay olmamıştır. $\mathrm{Bu}$ geniş coğrafya, elbette hiçbir devlet veya millet tarafindan Kazaklara hediye edilmemiştir. Kazakların özellikle son üç asrı bu toprakları koruma mücadeleleriyle geçmiş ve insanlık tarihinde yapılan ortalama beş bin savaşın yaklaşık bin beş yüzü Kazak yerinde olmuştur.

Coğrafyası bu kadar geniş, tarihi ise çok eskilere dayanan bu mekânlar, Göktürk Dönemi eski Türk dili yadigârları açısından da oldukça zengindir. Kazakistan coğrafyasında daha çok kayalar üzerinde bulunan bu damga ve yazıların uzunluğu çok uzun olmasa da son yıllarda yapılan inceleme ve araştırma gezileri sayesinde sayıları giderek artmaktadır.

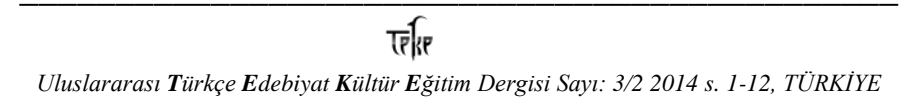


Son dönemlerde Kazak yerinde bulunan bu metinlerin okunuş biçimleriyle ilgili farklı görüşler de ortaya atılmaktadır. Hatta bazı metinlerin okunması hâlâ mümkün olamamıştır.

2009 ile 2012 yılları arasında Kazakistan coğrafyasında bulunan 9 adet Göktürk harfli metin, gelecekte de bu çalışmaların bu coğrafyada sürdürülmesi gereğini ortaya koymaktadır. $\mathrm{Bu}$ anlamda Kazakistan coğrafyası eski Türk dili alanındaki araştırmacıları beklemektedir.

\section{Kaynaklar}

Аманжолов А.С. (2003) - Две наскальные рунические надписи в долине Иртыша // История и теория древнетюркского письма. -Алматы: ЗАО «Издательство «Мектеп», 2003. -С. 203-204.

Базылхан Н. (2003) - Древнетюркская битик, фоно-морфемная структура письменности и проблемы интерпретации текстов // Тувинский институт гуманитарных исследований «Письменное наследия тюрков». Международный симпозиум, посвященный 110-летию дешифровки орхоно-енисейской письменности и 100 летию выхода в свет труда Н.Ф. Катанова «Опыт исследование урянхайского языка» 14-17 октября 2003 г. Тезисы. - Кызыл. 2003. - С.31-35

Базылхан Н. (2005) - Көне түрік бітіктастары мен ескерткіштері (Орхон, Енисей, Талас) // Серия:«Қазақстан тарихы туралы түркі деректемелері» -II том. -Алматы: ДайкПресс, 2005. -252 +144-б жапсырма. -245-245.

Базылхан Н. (2008) - Древнетюркские письменные памятники Казахстана //«Түркология».- №5-6 (37-38), қыркүйек-желтоқсан.- Түркістан, 2008. -117-122бб.

Базылхан Н., Железняков Б.А., Хермани Л., Жамбулатов К. (2013) - Находка памятника древнетюркской письменнотси в горах Кульжабасы (предварительное чтение) // V. халықаралық түркология конгресі.»мәдени ықпалдастық және өркениеттер бірлігі» баяндамалар жинағы. -Түркістан,: Қ.А. ясауи атындағы халықаралық қазақ-түрік университеті, 2013.- 664-669.

Васильев Д.Д. (2006) - Евразийский ареальный аспект руноподобной письменной культуры древних тюрков // Теория и методы исследования восточной эпиграфикии /отв.ред. Д.Д. Васильев; Инс-т востоковедения.-М.:Вост.лит.; 2006,311c.-30-43.

Кызласов И.Л. (1994) - Рунические письменности Евразийских степей. -Москва; Издательская фирма «Восточная литература» РАН, 1994. -327 с.:ил.

Кызласов И.Л. (2010) - Прочтение рунической надписи урочища Актерек // Роль номадов в формировании культурного наслдеия Казахстана. Научные чтения Н.Э. Масанова: Сб.мат-лов Межд. Науч. Конф.-Алматы:Print-S, 2010.- C.345-346 ($544 \mathrm{c} .+42$ с илл.)

Рогожинский А.Е. (2010) - Новые находки памятников древнетюркской эпиграфики и монументального искусства на юге и востоке Казахстана // Роль номадов в формировании культурного наслдеия Казахстана. Научные чтения Н.Э. Масанова: Сб.мат-лов Межд. Науч. Конф.-Алматы:Print-S, 2010.- C.329-344

Рогожинский А.Е. (2010) - Новые находки памятников древнетюркской эпиграфики и монументального искусства на юге и востоке Казахстана // Роль номадов в формировании культурного наслдеия Казахстана. Научные чтения Н.Э. Масанова: Сб.мат-лов Межд. Науч. Конф.-Алматы:Print-S, 2010.- 333 с. (-544c.+42 с илл.)

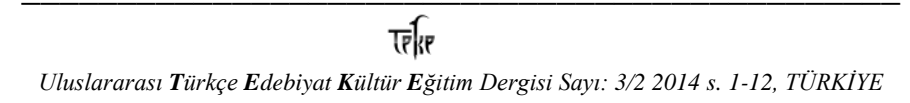

International Journal of Turkish Literature Culture Education Volume 3/2 2014 p. 1-12, TURKEY 
Рогожинский А.Е., Кызласов И.Л. (2004) - Древнетюркская руническая надпись из урочища Тамгалы (Семиречье) // Краткие сообщение института археологии РАН. Публикации и полевые исследования. - М., Вып. 216. 2004г.-С.41-46.

Самашев 3. Жетісу жартас суреттері. Баян-жүрек. Ә.Х. Марғұлан атындағы Археология институтының Астана қаласындағы баспа тобы. -Астана, 2012. -240б.

Смагулов Е.А. Продолжение исследования стратиграфии древнего Саурана // Мемлекеттік «Мәдени мұра» бағдарламасы бойынша 2008 жылғы Археологиялық зерттеулер жайлы есеп. -Алматы, 2009. Қазақ және орыс тілдерінде. -204-209 бб.

Табалдиев К., Белек К. Памятники письменности на камнях Кыргызстана. - Бишкек, 2008. $-336 \mathrm{c}$. 